\title{
LASER DESORPTION/IONIZATION MASS SPECTROMETRY (LDI MS) OF TERBIUM(III) COORDINATION COMPOUND WITH NEW BIS-CHELATING CARBACYLAMIDOPHOSPHATE (CAPh) LIGAND
}

\author{
${ }^{I}$ Taras Shevchenko National University of Kyiv \\ 64 Volodymyrska Str., Kyiv, 01601, Ukraine, E-mail: olishevetsirina@gmail.com \\ ${ }^{2}$ Chuiko Institute of Surface Chemistry of National Academy of Sciences of Ukraine \\ 17 General Naumov Str., Kyiv, 03164, Ukraine
}

\begin{abstract}
During last decades coordination compounds of lanthanides with polychelating $\beta$-diketones and their derivatives have attracted increasing interest due to the possibility of using such compounds in biomedical research, as contrast reagents for NMR tomography studies and MOLED technology. That is why the selection of appropriate ligands, which are effective sensitizers of lanthanide luminescence and can form thermodynamically stable complexes, is especially important.

Carbacylamidophosphates (CAPh ligands) of general formula $\left(R^{1}\right) C(O) N H P(O)\left(R^{2}\right)_{2}$ are structural analogues of $\beta$-diketones, which can serve as an antenna providing more efficient energy transfer to the lanthanide ion followed by Ln(III) luminescence.

The present work is devoted to the mass-spectrometric studies of the stability of coordination compound of terbium(III) with new CAPh ligand using methods of soft ionization such as matrix activated laser desorption / ionization (MALDI), its modification - LDI (laser desorption ionization). The main preference of the «soft ionization» methods is the possibility of unfragmented ions registration.

Terbium coordination compound with new bis-chelating carbacylamidophosphate ligand $\left(\mathrm{Tb}(\mathrm{HL})_{2}\left(\mathrm{NO}_{3}\right)\right)$ (where $\mathrm{HL}^{-}=$tetramethyl[pyridine-2,6-diyldi(iminocarbonyl)]diamidophosphate anion) has been synthesized and studied by IR spectroscopy and X-ray diffraction. It was shown that the deprotonated arm of each ligand is coordinated to the terbium ion in the bidentate manner and the protonated arm in monodentate manner via the oxygen atom of phosphoryl group. The nitrate ion is bidentate coordinated, completing coordination number of terbium to eight.

The components of the LDI mass spectrum of the synthesized coordination compound have been identified. The positive region of the mass spectrum of the complex $\mathrm{Tb}(\mathrm{HL})_{2}\left(\mathrm{NO}_{3}\right)$ is characterized by the presence of smaller fragments due to the effect of the metal ion on the fragmentation of the ligand molecules and the molecular ion is not observed due to formation of more complex and stable structures based on Tb(III) ions.
\end{abstract}

Keywords: laser desorption/ionization (LDIMS), terbium(III) coordination compounds, bis-chelating carbacylamidophosphates

\section{INTRODUCTION}

Coordination compounds of lanthanides with polychelating $\beta$-diketones and their derivatives lately have attracted especial attention due to the advancement of technology MOLED (metal organic light emitting devices) [1], as well as the possibility of using such compounds in biomedical research [2] and as contrast reagents for NMR tomography studies [3]. From this standpoint, the selection of appropriate ligands, which are effective sensitizers of lanthanide luminescence and can form thermodynamically stable complexes, is especially important.
Carbacylamidophosphates (CAPh ligands) of general formula $\left(\mathrm{R}^{1}\right) \mathrm{C}(\mathrm{O}) \mathrm{NHP}(\mathrm{O})\left(\mathrm{R}^{2}\right)_{2}$ are structural analogues of $\beta$-diketones, which can serve as an antenna providing more efficient energy transfer to the lanthanide ion followed by Ln(III) luminescence [4].

In present work, the results of massspectrometric studies of the coordination compound of terbium(III) with the ligand tetramethyl[pyridine-2,6-diyldi(iminocarbonyl)]diamidophosphate are presented.

The different methods of soft ionization such as matrix activated laser desorption / ionization (MALDI), its modification - LDI (laser 
desorption ionization) is widely employed for the investigation of complexes $[5,6]$. These methods allow us to get the information about composition of the complex (stoichiometric ratio of the components), to estimate the nature and stability of the complex particle and the character of intramolecular bonds due to analysis of the fragments and associates. The main preference of the «soft ionization» methods is a possibility of unfragmented ions registration.

\section{APPARATUS AND INSTRUMENTS}

The sample was prepared for the MALDITOF analysis as follows: $1 \mathrm{mg}$ of studied complex was dissolved in $1 \mathrm{ml}$ of water. Aliquots of mixture were applied to the steel tips and dried.

MS analysis was performed by the method of laser desorption/ionization on an Autoflex II (Bruker Daltonics, Germany) mass spectrometer with nitrogen laser $(\lambda=337 \mathrm{~nm})$. Experiments were carried out in reflectron mode for positive ions in the mass range 50 to 2000 a.m.u. Resulting mass spectra were obtained by assuming the data of 150 laser shots and processing by the software FlexAnalysis (Bruker Daltonics, Germany).

IR spectrum was recorded using a PerkinElmer Spectrum 100 FT-IR spectrometer over the frequency range $4000-400 \mathrm{~cm}^{-1}(\mathrm{KBr}$ pellets). The X-ray diffraction patterns were obtained with an Xcalibur-3 diffractometer (graphite monochromator, $\mathrm{Mo}_{\alpha}$ radiation).

\section{RESULTS AND DISCUSSION}

Preparation of $\mathrm{Tb}(\mathrm{HL})_{2}\left(\mathrm{NO}_{3}\right)$. The ligand and its sodium salt have been synthesized as reported in literature [7] with some modification. NaHL (4 mmol) was dissolved in $5 \mathrm{ml}$ of methanol and then added to a solution of $\mathrm{Tb}\left(\mathrm{NO}_{3}\right)_{3} \cdot 6 \mathrm{H}_{2} \mathrm{O}(2 \mathrm{mmol})$ in $5 \mathrm{ml}$ of 2-propanol. The precipitated $\mathrm{NaNO}_{3}$ was filtered off and kept undisturbed during a few days, until crystals were formed. The yield was $91 \%$. The singlecrystals were obtained from 2-propanol. To identify the impurities in the crystal powder, the $\mathrm{X}$-ray diffraction patterns method have been used. IR for $\mathrm{Tb}(\mathrm{HL})_{2}\left(\mathrm{NO}_{3}\right) \quad\left(\mathrm{KBr}, \quad v^{\cdot} \mathrm{cm}^{-1}\right)$ : $1208(\mathrm{PO}) ; 1598,1618 \quad(\mathrm{CO})$, for $\mathrm{H}_{2} \mathrm{~L}$ $\left(\mathrm{KBr}, v \cdot \mathrm{cm}^{-1}\right): 1252(\mathrm{PO}) ; 1628(\mathrm{CO})$, for $\mathrm{NaHL}$ $\left(\mathrm{KBr}, v \mathrm{~cm}^{-1}\right)$ : 1290 (PO); 1607 (CO). Two absorption bands from $\mathrm{CO}$ group vibrations can be explained by different type of coordination (monodentate or bidentate) [8]. The IR spectra of the sodium salt $\mathrm{NaHL}$ and $\mathrm{Tb}(\mathrm{HL})_{2}\left(\mathrm{NO}_{3}\right)$ reveal shifts of the characteristic stretching vibrations in comparison with the neutral ligand $\mathrm{H}_{2} \mathrm{~L}$ which indicate a significant delocalization of $\pi$-electron density in the CONPO fragment $\left(\Delta v_{\text {as }}(\mathrm{CO})=\right.$ $=10-30 \mathrm{~cm}^{-1}$, and $\left.\Delta v(\mathrm{P}=\mathrm{O})=38-46 \mathrm{~cm}^{-1}\right)[9,10]$. $\mathrm{X}$-ray diffraction study was carried out for $\mathrm{Tb}(\mathrm{HL})_{2}\left(\mathrm{NO}_{3}\right)$. The complex has a monomeric structure (Fig. 1). The deprotonated arm of each ligand is coordinated to the terbium ion in the bidentate bridging manner and the protonated arm in monodentate manner via the oxygen atom of phosphoryl group. The nitrate ion is bidentate coordinated, completing coordination number of terbium to eight.

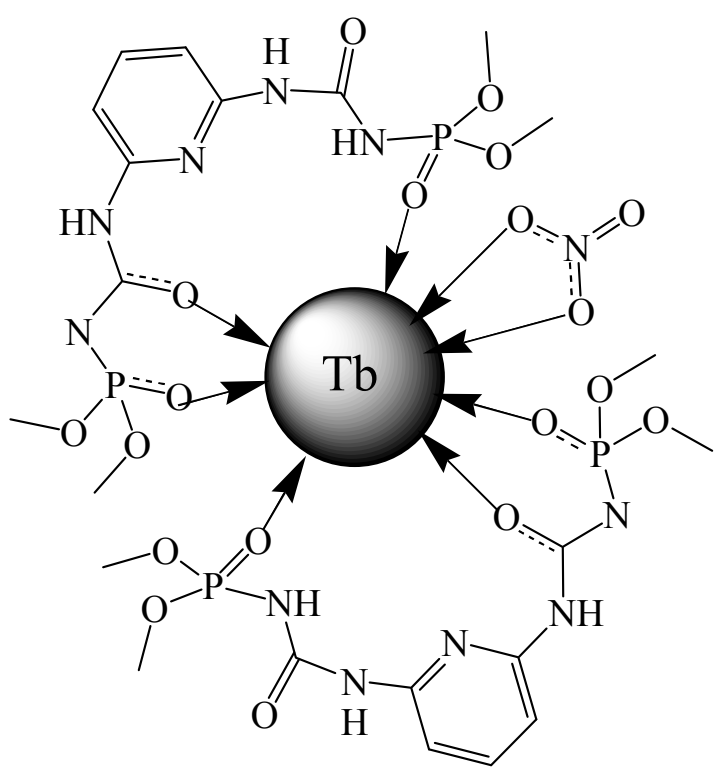

Fig. 1. Schematic representation of the coordination compound $\mathrm{Tb}(\mathrm{HL})_{2}\left(\mathrm{NO}_{3}\right)$

\section{MALDI TOF}

Method of laser desorption/ionization 'soft' ionization method - allows generating unfragmented molecular ions for the respective determination of the complex composition. But in our case the mass spectrum does not contain the molecular ion peak (calculated mass for the complex under consideration is equal to $1101 \mathrm{Da})$.

The positive region of the mass spectrum of the complex is characterized by the presence of smaller fragments due to the effect of the metal ion on the fragmentation of the ligand molecules. Due to the formation of more complicated and stable structures, the compound itself is not 
ionized and because of this, the molecular ion is not observed.

In the mass spectra of the complex (Fig. 2) there are peaks which can be attributed to the fragments with different ratio of terbium/ligand and their short-lived adducts with alkali metals ions $\left(\mathrm{Na}^{+}\right.$and $\left.\mathrm{K}^{+}\right)$. Experimental values and theoretically calculated mass of the core fragments are presented in Table.

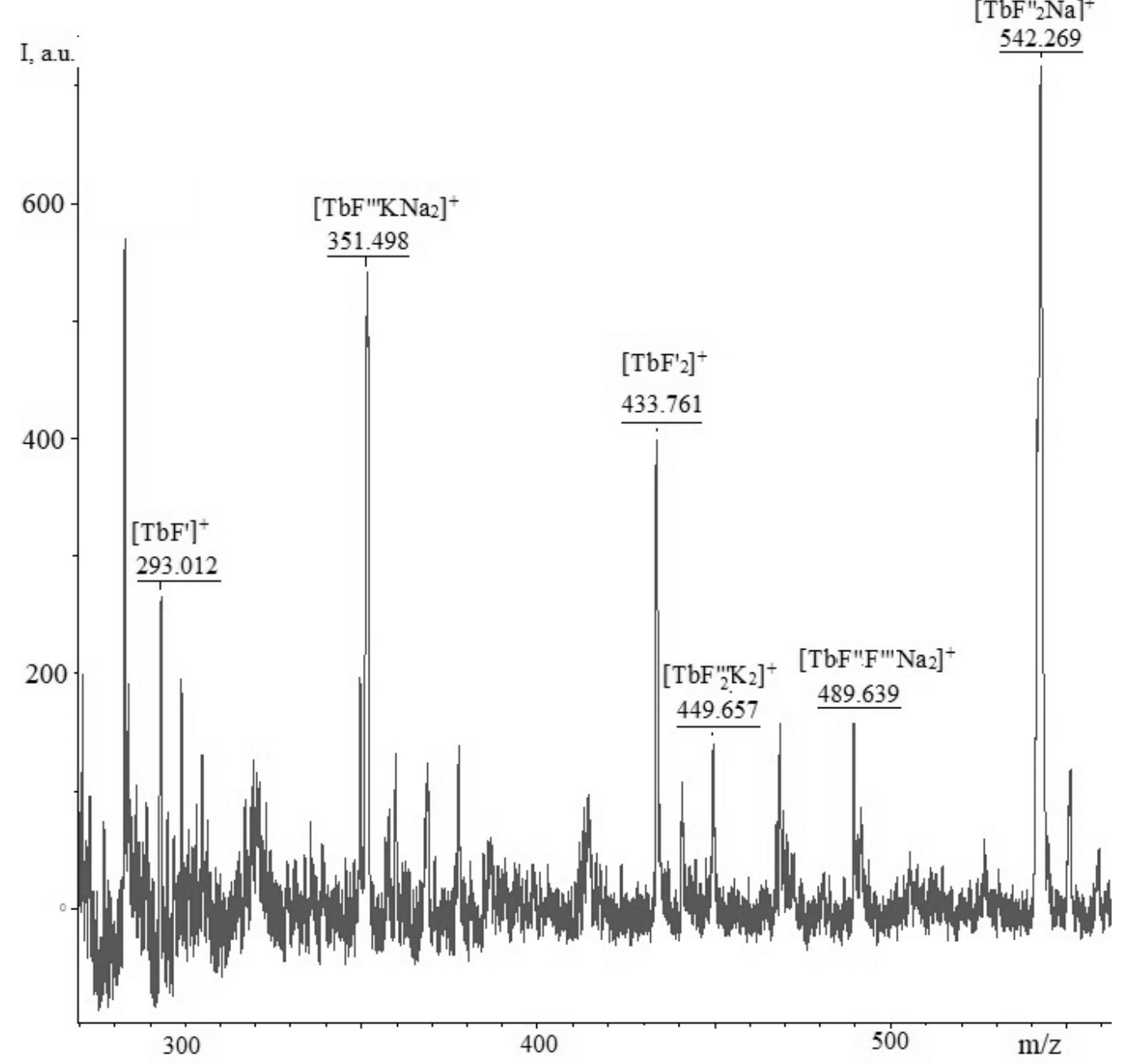

Fig. 2. Representative mass spectrum of terbium(III) complex under consideration

Table. Fragmentation of terbium(III) complex under conditions of MALDI TOF mass spectrometric experiment in the linear mode of positive ions

\begin{tabular}{cccc}
\hline & Fragment & $\boldsymbol{m} / \boldsymbol{z}$ Values & $\begin{array}{c}\text { The experimental mass } \\
\text { values, } \boldsymbol{m} / \boldsymbol{z}\end{array}$ \\
\hline 1. & {$\left[\mathrm{TbF}^{+}\right]^{+}$} & 294.97 & 293.01 \\
2. & {$\left[\mathrm{TbF}^{\prime \prime} \mathrm{KNa}_{2}\right]^{+}$} & 349.02 & 351.50 \\
3. & {$\left[\mathrm{TbF}_{2}\right]^{+}$} & 431.01 & 433.76 \\
4. & {$\left[\mathrm{TbF}^{\prime \prime} \mathrm{K}_{2}\right]^{+}$} & 447.15 & 449.66 \\
5. & {$\left[\mathrm{TbF"} \mathrm{F"'Na}_{2}\right]^{+}$} & 489.00 & 489.64 \\
6. & {$\left[\mathrm{TbF}_{2} \mathrm{Na}^{+}\right.$} & 540.60 & 542.27 \\
\hline
\end{tabular}


In the general mass spectra of the complex, series of peaks with masses from 85.9 to 196.4 Da, corresponding to the fragmentation of ligand, are presented. The next series of lowintensity peaks are presented in mass range from 282.8 to $542.3 \mathrm{Da}$ and belong to terbiumcontaining fragments: $\left[\mathrm{TbF}^{\prime}\right]^{+},\left[\mathrm{TbF}^{\prime \prime} \mathrm{KNa}_{2}\right]^{+}$, $\left[\mathrm{TbF}_{2}\right]^{+},\left[\mathrm{TbF}^{\prime \prime} \mathrm{K}_{2}\right]^{+},\left[\mathrm{TbF}^{\prime \prime} \mathrm{F}^{\prime \prime} \mathrm{Na}_{2}\right]^{+},\left[\mathrm{TbF}_{2}{ }_{2} \mathrm{Na}\right]^{+}$, where $\mathrm{F}^{\prime}-\mathrm{a}$ fragment of the ligand with the

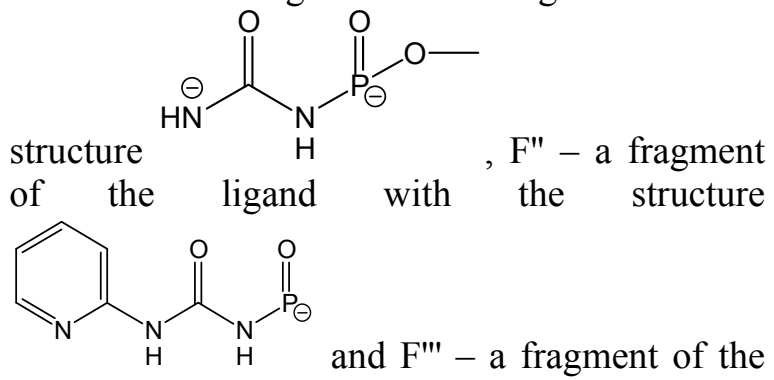

ligand with the structure $\mathrm{H}$ respectively.

The formation of such associates with alkali metals ions is characteristic for various classes of coordination compounds $[9,10]$. Low ionization capability of the formed fragments leads to low intensity of the respective peaks.

\section{CONCLUSION}

LDI mass spectrum of the terbium complex under investigation has been obtained and interpreted. It has been shown that the absence of molecular ion peaks testifies that the loss of one electron by complex molecule results in its destruction with formation of positively charged ion-fragments which probably corresponds to complex particles based on $\mathrm{Tb}(\mathrm{III})$ ions.

\title{
Лазерна десорбційна/іонізаційна (ЛДІ МС) мас-спектрометрія координаційної сполуки тербію(III) 3 новим біс-хелатуючим карбациламідофосфатним (КАФ) лігандом
}

\author{
І.П. Олишевець, О.В. Севериновська, В.А. Овчинніков, В.М. Амірханов \\ Київський Наџіональний університет ім. Тараса Шевченка \\ вул. Володимирська, 64, Киї,01601, Україна, olishevetsirina@gmail.com \\ Інститут хімії поверхні ім. О.О. Чуйка Національної академії наук Украйни \\ вул. Генерала Наумова, 17, Київ, 03164, Украӥна
}

Протягом останніх десятиліть координаційні сполуки лантаноїдів з поліхелатуючими $\beta$-дикетонами та їх похідними викликали все більший інтерес через можливість використання таких сполук у біомедичних дослідженнях, як контрастні агенти в ЯМР томографії та технології MOLED. Тому особливо важливим $\epsilon$ вибір відповідних лігандів, які є ефективними сенсибілізаторами люмінесценції лантаноїдів $i$ можуть утворювати термодинамічно стійкі комплекси.

Карбациламідофосфати (КАФ-ліганди) загальної формули $\left(R^{1}\right) C(O) N H P(O)\left(R^{2}\right)_{2} \quad \epsilon \quad$ структурними аналогами $\beta$-дикетонів, які можуть виступати як антени, забезпечуючи більш ефективне перенесення енергї̈ до іона лантаноїда, щчо супроводжується Ln(III) люмінесиениією.

Дана робота присвячена мас-спектрометричним дослідженням стійкості координаційної сполуки тербію(III) з новим КАФ-лігандом з використанням методів м'якої іонізації, таких як матрично активована лазерна десорбиія/іонізація (MALDI), її модифікація - LDI (лазерна десорбція/іонізація). Основною перевагою методів «м'якої іонізації» є можливість реєстрації нефрагментованих іонів.

Координаційна сполука тербію 3 новим біс-хелатуючим карбациламідфосфатним лігандом $\mathrm{Tb}(\mathrm{HL})_{2}\left(\mathrm{NO}_{3}\right)$, де $\mathrm{HL}^{-}=$тетраметилпіридин-2,6-диїл(імінокарбоніл)діамідофосфат аніон була синтезована та досліджена за допомогою ІЧ-спектроскопії та рентгенівської дифракиії. Показано, щзо депротонована гілка кожного ліганда координується до йона тербію бідентатно через атоми оксигену карбонільної та фосфорильної групи, а недепротонована гілка - монодентатно через атом оксигену фосфорильної групи. Нітрат-аніон координований бідентатно, доповнюючи координаційне число тербію до восьми. 
Компоненти LDI мас-спектру синтезованої координаційної сполуки було ідентифіковано. Позитивна область мас-спектру комплекса $\mathrm{Tb}(\mathrm{HL})_{2}\left(\mathrm{NO}_{3}\right)$ характеризується наявністю менших фрагментів через вплив іона металу на фрагментацію молекул ліганда, а молекулярний іон не спостерігається через утворення більш складних та стабільних структур на основі іонів Тb(III).

Ключові слова: лазерна десорбчія/ іонізачія (ЛДІ МС), координаційні сполуки тербію(III), біс-хелатуючі карбациламідофосфати

\title{
Лазерная десорбционная/ионизационная (ЛДИ МС) масс-спектрометрия координационного соединения тербия(III) с новым бис-хелатирующим карбациламидофосфатным (КАФ) лигандом
}

\author{
И.П. Олишевец, О.В. Севериновская, В.А. Овчинников, В.М. Амирханов
}

Киевский Наџиональный университет им. Тараса Шевченко

ул. Владимирская, 64, Киев,01601, Украина, olishevetsirina@gmail.com

Институт химии поверхности им. А.А. Чуйка Наџиональной академии наук Украинь

ул. Генерала Наумова, 17, Киев, 03164, Украина

В течение последних десятилетий координационные соединения лантаноидов с полихелатирующими $\beta$-дикетонами и их производными вызывали все больший интерес из-за возможности использования таких соединений в биомедиџинских исследованиях, в качестве контрастных агентов в ЯМР томографии и технологии MOLED. Поэтому особенно важным является поиск лигандов, которые являются эффективными сенсибилизаторами люминесценции лантаноидов и могут образовывать термодинамически устойчивые комплексы.

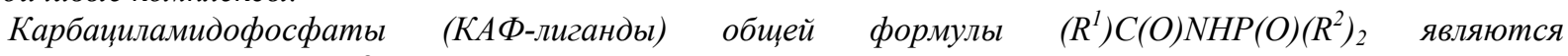
структурными аналогами $\beta$-дикетонов, которые могут выступать в качестве антенны и обеспечивать более эффективный перенос энергии к иону лантаноида с последующей Ln(III) люминесценцией.

Данная работа посвящена масс-спектрометрическим исследованиям устойчивости координационного соединения тербия(III) с новым КАФ-лигандом с использованием методов мягкой ионизации, таких как матрично активированная лазерная десорбция/ионизаџия (MALDI), ёе модификаџия - LDI (лазерная десорбция/ионизация). Основным преимуществом методов «мягкой ионизации» является возможность регистращии нефрагментированных ионов.

Координачионное соединение тербия с новым бис-хелатирующим карбациламидофосфатным лигандом $\mathrm{Tb}(\mathrm{HL})_{2}\left(\mathrm{NO}_{3}\right) \quad$ (где $\mathrm{HL}^{-}=$тетраметилпиридин-2,6-диил(иминокарбонил)диамидофосфат анион) было синтезировано и исследовано с помощью ИК-спектроскопии и рентгеновской дифракции. Показано, что депротонированная ветвь каждого лиганда координируется к иону тербия бидентатно через атомы кислорода карбонильной и фосфорильной группь, а недепротонироованная ветвь - монодентатно через атом кислорода фосфорильной группьl. Нитрат-анион координирован бидентатно, дополняя координационное число тербия до восьми.

Компоненты LDI масс-спектра синтезированного координационного соединения были идентифицированы. Положительная область масс-спектра комплекса $\mathrm{Tb}(\mathrm{HL})_{2}\left(\mathrm{NO}_{3}\right)$ характеризуется наличием меньших фрагментов из-за влияния иона металла на фрагментацию молекул лиганда, а молекулярный ион не наблюдается из-за образования более сложных и стабильных структур на основе ионов $\mathrm{Tb}(I I I)$.

Ключевые слова: лазерная десорбиия/ионизация (ЛДИ МС), координационные соединения тербия(III), бис-хелатирующие карбаџиламидофосфать 


\section{REFERENCES}

1. Kido J., Okamoto Y. Organo lanthanide metal complexes for electroluminescent materials. Chem. Rev. 2002. 102(6): 2357.

2. Bünzli J-C.G. Lanthanide luminescence for biomedical analyses and imaging. Chem. Rev. 2010. 110(5): 2729.

3. Rashid H.Ur., Yu K., Zhou J. Lanthanide(III) chelates as MRI contrast agents: A brief description. J. Struct. Chem. 2013. 54(1): 223.

4. Kariaka N.S., Trush V.A., Sliva T.Yu., Dyakonenko V.V., Shishkin O.V., Amirkhanov V.M. Synthesis and spectral studies of lanthanides coordination compounds based on N-(diphenyl-phosphoryl)-benzamide. The structure of N-(diphenylphosphoryl)-benzamide. J. Mol. Struct. 2014. 1068(1): 71.

5. Henderson W., McIndoe J.S. Mass Spectrometry of Inorganic, Coordination and Organometallic Compounds: Tools - Techniques - Tips. (John Wiley \& Sons, Ltd., 2005.)

6. Wyatt M. MALDI-TOFMS analysis of coordination and organometallic complexes: a nic(h)e area to work in. J. Mass Spectrom. 2011. 46(7): 712.

7. Shatrava Yu.O., Ovchynnikov V.A., Sliva T.Yu., Amirkhanov V.M., Skopenko V.V. Phosphorylated carbamides containing 2-aminothiazole and 2-aminopyridine - potential polydentate ligands. Reports of the National Academy of Sciences of Ukraine. 2009. 5: 180. [in Ukrainian].

8. Skopenko V.V., Amirkhanov V.M., Sliva T.Yu., Vasilchenko I.S., Anpilova E.L., Garnovskii A.D. Various types of metal complexes based on chelating $\beta$-diketons and their structural analogoues. Russ. Chem. Rev. 2004. 73(8): 737.

9. Chernii V.Ya., Kovalska V.B., Severinovskaya O.V., Tretyakova I.N., Losytskyy M.Yu., Yarmoluk S.M., Volkov S.V. MALDI mass spectrometry of zirconium and hafnium dibenzoylmethanate phthalocyanines. $U k r$. Chem. J. 2012. 78(11): 20. [in Ukrainian].

10. Severinovskaya O.V., Mischanchuk A.V., Trush V.A., Prytula A.Yu., Amirkhanov V.M., Pokrovskiy V.A. Laser desorption/ionization (LDI MS) and thermoprogrammed desorption mass spectrometry (TPD MS) of europium(III) coordination compound with $\mathrm{N}$-\{bis[methyl(phenyl)amino]phosphoryl $\}$ benzenesulfoneamide. Him. Fiz. Tehnol. Poverhni. 2014. 5(4): 467. 